\title{
De neoliberais e de keynesianos em tempos de
} Coronavírus

De neoliberais e de keynesianos em tempos de Coronavírus

Des néoliberales et des keynesians en temps de coronavirus

Neoliberales y keynesianos en tiempos de coronavirus

Neoliberals and Keynesians in times of Coronavirus

\section{Carlos Walter Porto-Gonçalves}

\section{(Q) OpenEdition}

\section{Journals}

Edição electrónica

URL: http://journals.openedition.org/espacoeconomia/11699

DOI: 10.4000/espacoeconomia.11699

ISSN: 2317-7837

Editora

Núcleo de Pesquisa Espaço \& Economia

Refêrencia eletrónica

Carlos Walter Porto-Gonçalves, "De neoliberais e de keynesianos em tempos de Coronavírus »,

Espaço e Economia [Online], 18 | 2020, posto online no dia 14 abril 2020, consultado o 20 maio 2020.

URL : http://journals.openedition.org/espacoeconomia/11699; DOI : https://doi.org/10.4000/ espacoeconomia.11699

Este documento foi criado de forma automática no dia 20 maio 2020

(c) NUPEE 


\title{
De neoliberais e de keynesianos em tempos de Coronavírus
}

\author{
De neoliberais e de keynesianos em tempos de Coronavírus \\ Des néoliberales et des keynesians en temps de coronavirus \\ Neoliberales y keynesianos en tiempos de coronavirus \\ Neoliberals and Keynesians in times of Coronavirus
}

\section{Carlos Walter Porto-Gonçalves}

1 Sim, de repente, "somos todos keynesianos", afirma o liberal Armínio Fraga, recuperando a frase de uma de suas fontes de inspiração: Milton Fridman. Ele que, junto com outros economistas, foi responsável por institucionalizar o rentismo enquanto estrutura de poder que consagrou uma aliança de todas as classes proprietárias no Brasil com o Plano Real, o grande ajuste dos ajustes: o ajuste de classe. O Brasil, desde 1994, viu sua dívida pública passar de cerca de 60 bilhões para 750 bilhões de reais nos governos FHC (1994-2002); para 1 trilhão e 500 bilhões de reais nos governos Lula da Silva (2003-2010); para mais de 3 trilhões nos governos Dilma Rousseff (2011-2016) e para mais de 4 trilhões no governo Temer (2016-2018). Nesse mesmo período, entre 1994 e 2018, o setor industrial viu sua contribuição para o PIB cair de $26 \%$ para cerca de $10 \%$ !

2 Vários dos colaboradores do Plano Real, como o Sr. Armínio Fraga, logo depois fundaram bancos ou foram trabalhar como CEOs nas principais instituições financeiras. Com certeza, cabe o epíteto de bankster a essa gente. Hoje o país se vê sem condições de produzir internamente até mesmo máscaras de proteção tão necessárias na pandemia do coronavírus, para não falar do sucateamento do sistema de saúde cujas verbas não cessaram de cair em nome do superávit fiscal garantido por uma lei de responsabilidade fiscal acima do direito à vida, pois se assim fosse implicaria uma lei de responsabilidade social ou, no mínimo, sanitária. Felizmente, a resistência de setores que sabem da importância desse bem comum, que é a saúde coletiva, foi capaz de manter, até onde foi possível, o SUS e, com isso, garantir um mínimo para que se pudesse enfrentar a atual crise em que todos estamos metidos, até mesmo sob o 
comando de um dos seus detratores e operador da medicina privada, como o atual Ministro da Saúde. Registre-se que o Sr. Mandetta, pelo menos, teve a virtude de mudar de posição na hora que viu o bicho pegar e passar a vestir o colete do SUS por todo lado onde vai.

E olha que todos esses ultraliberais de estado mínimo para o povo e estado máximo para o capital, agora se veem como keynesianos. Mas, atenção!, não há nenhuma contradição em ser ultraliberal e keynesiano, dependendo da ocasião (e da conveniência). A experiência chilena o demonstrou amplamente com os "chicago's boys" chegando a Santiago em 1976, depois da chacina iniciada por Augusto Pinochet em 1973. Todos sabemos, ou deveríamos saber, que a primeira experiência neoliberal do mundo, a chilena, nasceu sob cadáveres. Enfim, tivemos nos últimos 50 anos um estado liberal tão onipresente na economia como o foi o estado soviético tão criticado por seus ideólogos. No entanto, à diferença daquele, o estado neoliberal é, antes de tudo, um estado que abandona a nação e, como aquele, um estado que prescinde da democracia, o que mereceu uma certeira caracterização de Aníbal Quijano, quando afirmou que estamos diante de um estado des-democratizado e des-nacionalizado, nesse caso indicando um estado que abandonou a nação num sentido mais profundo que vai mais além da estrangeirização.

o keynesianismo, devíamos saber, é um conjunto de políticas de um capitalismo moribundo, em decadência, procurando equilibrar-se lançando mão de artifícios que vão além do mercado, para salvá-lo. Não nos surpreendamos quando em seus momentos de crise aguda a mão visível do estado se faça presente para resolver o que a mão invisível do mercado não consegue. O caráter defensivo do capitalismo é explicitado com o keynesianismo seja na sua versão do New Deal estadunidense, seja na sua vertente hitleriana. $\mathrm{O}$ keynesianisno acusa o golpe dos avanços das lutas operárias e populares que haviam abalado o mundo (John Reed) com a revolução comunista de 1917, ainda não degenerada pelo stalinismo, e pela forte presença do movimento sindical na Europa ocidental e nos EEUU. Keynes pragmaticamente sabia da importância de um sindicalismo forte para garantir que a demanda efetiva não iria cair. $\mathrm{Na}$ verdade, o keynesianismo reconhecia uma situação de fato da correlação de forças políticas e canalizou a política para o estado e, com isso, garantindo a hegemonia burguesa seja com a democracia representativa, caso dos EEUU, ou não, caso da Alemanha e da Itália. Diga-se, de passagem, que o mesmo se passava com a degeneração da revolução russa com seu estado cada vez mais fortalecido que esvaziou os sovietes que a protagonizara - "Todo poder aos sovietes". Apesar desse brado da revolução de outubro, em 1989, depois de 72 anos, a URSS desmoronava sem que houvesse um só soviete para defendê-la. Ali, também, o máximo de estado e o mínimo de sociedade auto organizada como os soviets. Enfim, por todo lado o estado passou a ser o centro da política, pelas direitas e pelas esquerdas. Pelas esquerdas passou a dominar o que o saudoso mestre I. Wallerstein, viria chamar de estratégia dos dois passos: primeiro passo, tomar o poder do estado; segundo passo, mudar o mundo. Seja pela via reformista -socialdemocracia e nacional desenvolvimentismo -, seja pela via revolucionária - comunismo e nacionalismo revolucionário - o estado ganhou tal centralidade a ponto de se tornar um verdadeiro "obstáculo cognitivo", como viria chamar Rachel Gutierrez. É para isso que chamamos a atenção o que agora aparece com o keynesianismo sendo a tábua de salvação diante da crise sistêmica explicitada por um vírus. E nesse momento nada melhor que a inspiração de I. Wallerstein que nos ensinara que o estado até pode ser uma necessidade, mas, com certeza, não é o lugar da 
virtude. Talvez seja essa a grande lição do século XX. Cuidemo-nos para que a necessidade de alguma ordem, típica de momentos de caos, não seja a defesa de qualquer ordem, muito menos a volta da ordem que nos deu esse caos. Enfim, um mundo para além do liberalismo seja pela direita, seja pela esquerda.

E o estado, sabemos, é sempre a política sobre a sociedade, na melhor estratégia jamais concebida ao se apresentar como se fosse em nome do interesse de todos. Máximo fetiche que Maquiavel já havia desnudado em suas tecnologias de poder, muito antes de Marx ou Foucault.

\section{RESUMOS}

Políticas econômicas emergem e desaparecem conforme interesses do Estado e do grande capital. Em momentos de expansão, keynesianos tornam-se neoliberais. Em momentos de crise, neoliberais tornam-se keynesianos. Em comum a ambos o fato de que os prejuízos são sempre pagos com dinheiro público.

Politiques économiques naissent et disparaissent selon les intérêts de l'État et du grand capital. Ainsi, les keynesians sont devenus néoliberales aux moments d'expansion capitaliste, mais les mêmes néoliberales sont devenus keynesians aux moments de crise. Ce qui est commun aux deux, c'est le fait selon lequel les pertes sont toujours payées avec l'argent publique.

Las políticas económicas surgen y desaparecen según los intereses del Estado y las grandes empresas. En tiempos de expansión, los keynesianos se vuelven neoliberales. En tiempos de crisis, los neoliberales se convierten en keynesianos. En común con ambos, el hecho de que las pérdidas siempre se pagan con dinero público.

Economic policies emerge and disappear according to the interests of the State and big capital. In times of expansion, Keynesians become neoliberal. In times of crisis, neoliberals become Keynesians. In common with both, the fact that losses are always paid for with public money.

\section{ÍNDICE}

Mots-clés: Covid-19 ; néoliberalisme; keynesianisme; l'État ; le grand capital.

Keywords: Covid-19; neoliberalism; Keynesianism; State; big capital.

Palabras claves: Covid-19; neoliberalismo; keynesianismo; Estado; gran capital.

Palavras-chave: Covid-19; neoliberalismo; keynesianismo; Estado; grande capital.

\section{AUTOR}

\section{CARLOS WALTER PORTO-GONÇALVES}

Laboratório de Estudos de Movimentos Sociais e Territorialidades (LEMTO), Programa de PósGraduação em Geografia, Universidade Federal Fluminense, cwpg@uol.com.br 